\title{
Transformacja dzielnic staromiejskich w Polsce i Niemczech po 1989/1990 roku
}

\author{
Piotr Fiuk \\ Katedra Historii i Teorii Architektury, Wydział Budownictwa i Architektury, \\ Zachodniopomorski Uniwersytet Technologiczny w Szczecinie
}

Streszczenie: Proces transformacji Starych Miast stanowi złożone zagadnienie, którego skuteczna realizacja opiera się na synergii pojedynczych osób i lokalnej społeczności, wspieranych przez administrację, instytucje publiczne, środowiska naukowe i prywatnych przedsiębiorców; wykorzystuje sprzyjające okoliczności społeczno-polityczne, uwarunkowania ekonomiczne i koniunkturę gospodarczą. Zjawisko transformacji zespołów staromiejskich wiąże się ze zmianami ustrojowymi w Polsce po 1989 oraz Niemczech, po zjednoczeniu w 1990 r. podzielonego po II wojnie światowej państwa. W największym zakresie wystąpiło w ośrodkach miejskich, których zabytkowe centra nie zostały odbudowane po zniszczeniach z lat 1939-45 (Elbląg, Kołobrzeg, Szczecin-Podzamcze), lub zabudowane według modernistycznych koncepcji, które nie zaspokoiły oczekiwań mieszkańców i nie uzyskały akceptacji specjalistów (przede wszystkim historyków sztuki, konserwatorów zabytków i architektów o konserwatywnych poglądach), dążących do przywrócenia zrujnowanego krajobrazu staromiejskiego (Drezno, Frankfurt n/M, Hildesheim, Szczecin).

Słowa kluczowe: Transformacja, odbudowa, rekonstrukcja, architektura starych miast, współczesna kamienica.

\section{Wprowadzenie}

W wybranych polskich i niemieckich miasta na przełomie lat 80 i 90 XX w. nastąpił proces przywrócenia tożsamości kulturowej i odtworzenia utraconego wizerunku architektonicznego najstarszych dzielnic - uruchomiony w przełomowym okresie zmian systemowych, sprzężonych z perspektywami rozwoju, modernizacji gospodarczej, wiążących się również z określeniem priorytetów przez opinię publiczną i społeczności lokalne, w różnych dziedzinach funkcjonowania współczesnych ośrodków miejskich i aglomeracji. W odniesieniu do miast historycznych związanych z planami przywrócenia zrujnowanych układów przestrzennych i rekonstrukcją najcenniejszych budowli (Elbląg, Szczecin). Inicjatywy społeczne - których intencji nie poddawano w wątpliwość (kościół Marii Panny - Frauenkirsche w Dreźnie, Knochenhaueramtshaus przy Marktplatz w Hildesheim, barokowe fasady kamienic na Podzamczu w Szczecinie), ale też wzbudzające emocje wśród uczestników kampanii na rzecz odbudowy historycznych budowli oraz kontrowersje specjalistów (zamki w Berlinie, Hanowerze, Poczdamie, Komendantura przy Unter den Linden w Berlinie) — doprowadziły do podjęcia dyskusji, akcji informacyjnopopularyzatorskich, w konsekwencji rozpoczęcia prac nad rekonstrukcją i odtworzeniem ważnych dla przywrócenia charakteru dawnych miast, architektonicznych pomników przeszłości. 


\section{Odbudowa dawnych miast w Polsce po 1989 i Niemczech po 1990 r.}

W Polsce do 1989 r. nielicznymi dużymi miastami, w których nie odtworzono dawnego układu i nie doprowadzono do współczesnej zabudowy historycznych centrów, były najstarsze dzielnice Głogowa, Elbląga, Kołobrzegu i Szczecina (Podzamcze). W okresie transformacji po 1989 r. zaistniały okoliczności, umożliwiające odbudowę historycznej struktury zabudowy, którą prowadzono po wykonaniu wszechstronnych badań i wielostronnych przygotowaniach organizacyjno-prawnych, z udziałem instytucji publicznych, urzędów oraz prywatnych właścicieli i indywidualnych użytkowników - w okresie powrotu systemu gospodarki wolnorynkowej nastąpiło odtworzenie właściwej zasady własności, którą odzwierciedlała różnorodność poszczególnych kamienic, tworząc kalejdoskop rozwiązań w panoramie zespołów staromiejskich.

Odbudowę zdegradowanych historycznych dzielnic podjęto w Polsce po przełomie systemowym 1989 r. Uruchomienie procesu rewitalizacji związane było z powstaniem warunków dla prowadzenia wolnorynkowej działalności gospodarczej. Rozpoczęto przywracanie w starych dzielnicach ich właściwej struktury własnościowej i funkcjonalnej. Odbudowa historycznych centrów realizowana była według dalekosiężnego założenia: odzyskania w zdegradowanych historycznych miastach lokalnej tożsamości kulturowej i społecznej. Proces transformacji układów przestrzennych i zabudowy dawnych ośrodków miejskich, zrujnowanych podczas II wojny światowej oraz w okresie powojennej administracji PRL, realizowany był w znaczących miastach Ziem Zachodnich i Północnych (nazywanych po 1945 r. „Ziemiami Odzyskanymi”): Elblągu, Gdańsku, Głogowie, Kołobrzegu, Szczecinie, Stargardzie, Kostrzynie nad Odrą oraz mniejszych, cennych pod względem historycznym miasteczkach.

Realizacje w obrębie zabytkowych dzielnic - motywowanych względami historycznymi i kulturowymi - odzwierciedlają możliwości organizacyjno-techniczne, warunki gospodarczo-ekonomiczne i potrzeby przedsiębiorców, dla przeprowadzenia rozległego zakresu inwestycji, wymagających na obszarach objętych ochroną archeologicznokonserwatorską wieloetapowych badań, ekspertyz, studiów, których zwieńczenie stanowią urbanistyczno-architektoniczne projekty, poddawane złożonej procedurze uzgodnień archeologiczno-konserwatorskich i urbanistyczno-architektonicznych, także konsultacjom społecznym.

Podejmowane prace nad odtwarzaniem dawnego układu przestrzennego miast historycznych, przywracaniem wyglądu zrujnowanych zabytków oraz budową nowych kamienic, które skalą i cechami kompozycyjnymi nawiązują do dawnej zabudowy - niezależnie od krytycznych opinii części środowiska urbanistów, architektów, historyków i konserwatorów - w okresie fundamentalnych zmian systemowych, prawnych (przywrócenie zasady własności prywatnej w państwach Europy Środkowo-Wschodniej), gospodarczego rozwoju z udziałem prywatnych przedsiębiorców (odtworzenie dawnej struktury indywidualnych właścicieli kamienic) - stanowią istotne czynniki w odzyskiwaniu tożsamości kulturowej i określeniu odrębności współczesnych miast.

Inwestycje w zabytkowych centrach realizowały przede wszystkim spółdzielnie mieszkaniowe i firmy developerskie - w mniejszej części prywatni inwestorzy; podkreślić należy, że indywidualność formalno-plastyczna wyróżniająca zabudowę dawnych organizmów miejskich tworzona była staraniem kolejnych pokoleń kupców, mieszczan i patrycjuszy. Obszerny zakres prac, złożony harmonogram cyklu realizacyjnego, niewielkie zróżnicowanie układów funkcjonalnych, zastosowane materiały, technologie budowlane, 
rozwiązania detali wpłynęły w kolejnych etapach inwestycji na zacieranie się indywidualnych koncepcji autorskich, które - według wcześniejszych założeń - miały odzwierciedlić niepowtarzalny charakter odbudowywanego historycznego układu przestrzennego. Większą indywidualność osiągnięto w realizacjach, które stanowiły mniejszy zakres inwestycyjny.

\subsection{Elbląg}

W Elblągu kompleksowy program konserwatorski zakładał przywrócenie dawnego układu przestrzennego miasta z jego głównymi elementami: planem dróg, zarysem kwartałów, liniami zabudowy, podziałami katastralnymi i indywidualnością architektoniczną nowych kamienic - sytuowanych na zachowanych murach piwnicznych. Właśnie nienaruszalna zasada wznoszenia współczesnych domów na obrysie dawnych kamienic kupieckich wyróżniała elbląski program konserwatorski, nazwany przez jej współautorkę M. Lubocką-Hoffmann, Wojewódzkiego Konserwatora Zabytków: „retrowersją”.

Prace projektowe poprzedzały interdyscyplinarne badania naukowe. Poszczególne etapy projektowania i realizacji były koordynowane przez zespół specjalistów, tworząc warunki dla wykreowania zharmonizowanej panoramy przywracanego do życia historycznego centrum. Kamienice otrzymały indywidualne formy architektoniczne, nawiązujące do nastroju i ogólnego charakteru dawnego portowego ośrodka z charakterystyczną dla miast Europy Północnej przewagą osiowych elewacji i szczytowych układów dachów, których kupiecką tradycję podkreślają zrekonstruowane charakterystyczne formy przedproży.

Autorzy kolejnych faz koncepcyjnych i przeważającej liczby nowych kamienic S. Baum i R. Semka - wraz z W. Andersem w latach 1976-78 stworzyli studium projektowe zabudowy Starego Miasta w Elblągu. O architekturze nowych elbląskich kamienic odmienne opinie wyrażali architekci, konserwatorzy zabytków i historycy: od bardzo przychylnych, za ich niepowtarzalną i twórczą estetykę oraz atrakcyjność i bogactwo formalne, do bardziej sceptycznych ze względu podobieństwo kompozycyjnych poszukiwań.

Model elbląski stał się po 1989 r. wzorem dla odbudowy zespołów staromiejskich w innych miastach Polski, min: Fromborka, Głogowa, Kołobrzegu, Kostrzyna nad Odrą, Olsztyna, Płocka, Szczecina.

\subsection{Szczecin}

W Szczecinie inicjatorką odbudowy najcenniejszego fragmentu Starego Miasta Podzamcza była w 1982 r. K. Loose-Grabowska, autorami programu konserwatorskiego z lat 90. XX w. architekci: T. Balcerzak, H.J. Kustosz, S. Latour przy współudziale E. Staneckiej, Wojewódzkiego Konserwatora Zabytków. Dzięki skoordynowanej pracy wieloosobowych zespołów architektonicznych Podzamcze wyróżniło się zindywidualizowaniem kompozycyjnych i plastycznym nowych kamienic. Szczególną inicjatywą było zaproszenie do współpracy przy projektowaniu wybranego kwartałów utytułowanych architektów: S. Bauma, M. Budzyńskiego, K. Chawaliboga, A. Dudę i H. Zubela (w duecie), M. Fikusa, J. Gurawskiego, R. Jurkowskiego, A. Kicińskiego, B. Krzyżanowskiego, S. Kuryłowicza, J. Lenarta (koordynacja), S. Niemczyka, A. Miklaszewskiego, R. Semkę. 


\subsection{Frankfurt nad Menem}

Szczególny zakres prac nad przywróceniem dawnego charakteru architektury Starego Miasta podjęto we Frankfurcie nad Menem; decydując o wyburzeniu fragmentów powojennej modernistycznej zabudowy, która powstała w okresie „powrotu do życia” zrujnowanego miasta po upadku III Rzeszy, odzyskującego po latach pozycję finansowego centrum Europy. Przywracanie wyglądu najcenniejszych dzieł architektonicznych, odbudowa dawnej struktury przestrzennej z wznoszeniem replik oraz nowych kamienic, które skalą i formami nawiązują do nastroju zburzonych siedzib patrycjatu i kupiectwa, stanowią wieloletni proces przywracania tożsamości kulturowej dzielnicy staromiejskiej a także określają w okresie koniunktury wizerunek historycznego centrum nowoczesnej aglomeracji.

\subsection{Drezno}

Zmiany systemu politycznego we wschodniej części zjednoczonych Niemiec umożliwiły podjęcie prac nad rekonstrukcją centralnego fragmentu zespołu staromiejskiego w Dreźnie, uznanej za symbol zjednoczenia podzielonego państwa, jednocześnie przedstawiając odtwarzanie architektonicznych pomników przeszłości jako przestrogę dla następnych pokoleń (pomnikiem dla ofiar bombardowań wojennych - „Mahnmal für die Opfer des Bombenkrieges" $\left.{ }^{1}\right]$ - symbolem wojennego kataklizmu w czasach NRD było pozostawienie w stanie ruiny barokowych reliktów najważniejszego w Saksonii ewangelickiego kościoła:).

\section{Staromiejski kontekst nowej architektury}

Po 1945 r. z tętniących życiem kupieckich i portowych centrów wielu miast europejskich ulotnił się bezpowrotnie genius loci starych dzielnic z niepowtarzalną atmosferą sklepów kolonialny i eleganckich domów towarowych. Współcześnie podejmowane są próby odbudowy układów przestrzennych i właściwego zagospodarowania zniszczonych dzielnic zabytkowych, przywracającego dawny charakter miejsca. Zaakceptowano umowność podejmowanych starań nad odtworzeniem wyglądu zniszczonych historycznych domów, zespołów zabudowy i rekonstrukcją najcenniejszych dzieł architektonicznych (pomimo niemożliwości przywrócenia cech, określających niepowtarzalność oryginalnych dzieł sztuki i dawnego bogactwa). Do niefortunnych należą bezpośrednie powtórzenia $\mathrm{i}$ bezrefleksyjne cytaty $\mathrm{z}$ historii, znane $\mathrm{z}$ realizacji nowych budynków lub przebudowy modernistycznych bloków z powtarzalnymi klatkami schodowymi w obrębie zespołów staromiejskich (Chojnice, Gorzów Wielkopolski, Legnica). Zaryzykować można twierdzenie, że nie jest możliwe zaproponowanie współcześnie takiego modelu zabudowy w obrębie Starych Miast, który zostanie w pełni i bez dyskusji zaakceptowany, zarówno przez architektów, konserwatorów, historyków sztuki, jak i użytkowników, mieszkańców oraz przeważającą grupę lokalnej społeczności.

Przez stulecia kalejdoskop indywidualnych form architektonicznych określał tożsamość miast Starego Kontynentu, chociaż ich ewolucja pod względem formalnoplastycznym i technologicznym wynikała również z utylitarnego dostosowania do bieżą-

\footnotetext{
${ }^{1}$ Mak G. 2004. W Europie. Podróże przez dwudziesty wiek, Warszawa, Państwowy Instytut Wydawniczy, s. 555.
} 
cych potrzeb i upodobań. Kataklizmy XX w. zachwiały harmonię krystalizowanego przez stulecia pejzażu bogatych ośrodków miejskich. Po 1945 r. zrealizowano wielkie programy odbudowy i rekonstrukcji najcenniejszych zespołów staromiejskich. Równolegle powstawały interesujące koncepcje ich nowoczesnej zabudowy, jednak niezadowalające efekty wielu takich projektów zarysowały niechęć do lokalizowania awangardowej architektury w zabytkowym sąsiedztwie - kryzys modernistycznej urbanistyki oraz blokowej zabudowy osiedli i starych miast uwidocznił się w poglądach, które poddawały w wątpliwość możliwości twórcze nowej generacji projektantów dla współczesnego wykreowania wartościowych zjawisk architektonicznych, właściwych do zestawienia z artystycznym dziedzictwem przeszłości. Podkreślić należy: kontekst historyczny znakomicie podkreśla walory nowoczesnej architektury. Inspirujące są liczne przykłady udanego zestawienia współczesnych form z zabytkowym krajobrazem miast europejskich. Szacunek względem dziedzictwa przeszłości nie tworzy zastosowanie powtórzeń formalnych i podporządkowanie utartym konwencjom stylistycznym, znanym z dawnych epok. Do wartościowych należą oryginalne i twórcze koncepcje, zachowujące właściwą skalę względem otoczenia, harmonię z sąsiadującymi zróżnicowanymi kompozycjami, które poprzez kreatywne odzwierciedlenie w nowych rozwiązaniach charakterystycznych cech i nastroju epoki współtworzą ciągłość artystycznej ewolucji architektury dawnych miast. Najciekawsze projekty, wyróżniające się oryginalnością kompozycji, wyważonymi proporcjami i niekonwencjonalnym wyrazem plastycznym, powstały w zabytkowych dzielnicach min.: Barcelony, Bydgoszczy, Florencji, Gdańska, Hamburga, Kolonii, Krakowa, Mediolanu, Münster, Poznania, Szczecina, Warszawy, Wenecji, Wrocławia i innych. Historyczna atmosfera sprzyja wykreowaniu rozwiązań architektonicznych, odzwierciedlających wyważony kontrast nowoczesności z dawnymi budowlami.

Układy średniowiecznych placów targowych i sąsiednich kwartałów poddano procesowi przekształceń w zakresie struktur współczesnych aglomeracji - jako miejsce o szczególnych wartościach historyczno-kulturowych, funkcjonalno-przestrzennych, związanych ze sferą emocjonalną lokalnej społeczności; stanowią centrum kulturowe, duchowe i intelektualne, przyciągające turystów i integrujące mieszkańców, wyróżniają się także jako centralny obszar względem peryferii rozrastających się aglomeracji XX i XXI w. Centralne położenie i artystyczna atrakcyjność spowodowały przekształcanie zabytkowych dzielnic najbogatszych miast europejskich, w wytworne miejsca z ekskluzywnymi apartamentami, salonami wystawienniczymi i galeriami.

Działki położone $\mathrm{w}$ granicach średniowiecznych miast należą do cennych terenów inwestycyjnych. Ograniczona oferta atrakcyjnych terenów wpływa na podniesienie ich wartości, niezależnie od złożoności procesu budowlanego, ponoszonych nakładów, zakresu zadań technicznych na terenach o słabej nośności, stanowiącej wyznanie pod względem posadowienia i fundamentowania.

W wielu dzielnicach wyznaczonych na podstawie średniowiecznych przywilejów lokacyjnych (również śródmiejskich układach przestrzennych z XIX/XX w.) wymagane jest przeprowadzenie strukturalnej modernizacji starej substancji budowlanej, dokonanie uzupełnień, przywrócenie właściwego kształtu zdegradowanego krajobrazu kulturowego. Proces transformacji ustrojowej Polski stworzył po 1989 r. warunki dla przeprowadzenia procesów rewitalizacji zaniedbanych zabytkowych układów przestrzennych; skomplikowany, długotrwały i kosztowny zakres tych prac został urzeczywistniony w niewielkim zakresie.

W ostatnich dwóch dekadach XX w. wykrystalizowane zostały odmienne koncepcje urbanistyczne i architektoniczne przywrócenia odpowiedniego kształtu dawnych dzielnic. 
W zniszczonych miastach Polski Zachodniej i Północnej nie odbudowanie po wojennym kataklizmie regularnej przestrzeniu rynku staromiejskiego i pierzei indywidualnych kamieniczek, wiązało się - po upadku PRL, utożsamianego w zakresie budownictwa z unifikacją monotonnej blokowej zabudowy - z artykułowaniem przez napływową ludność potrzeby określenia własnej tożsamości i identyfikacji z nowym miejscem zamieszkania. Dużą popularność zyskiwały koncepcje przywracania dawnego wyglądu placów i zniszczonych domów, których dawne, atrakcyjne formy architektoniczne znane były $\mathrm{z}$ archiwalnych rycin i fotografii. Fascynacja przeszłością zrodziła bogatą edycję reprintów, których publikacja nie była możliwa w minionej epoce. Nowe tendencja, początkowo w zakresie idei, została rozwinięta w realizowanych planach przebudowy powojennych, nie lubianych „nowoczesnych” obiektów (Kołobrzeg) oraz rekonstrukcji wybranych elewacji, wyróżniających się bogactwem detali i oprawy plastycznej (Berlin, Brunszwik, Hildesheim, Szczecin).

Źle oceniono koncepcje architektoniczne, które realizowano w granicach zabytkowych dzielnic bez przygotowania wstępnej fazy badań archeologicznych, konserwatorskich oraz pogłębionej naukowej analizy historycznej. Na podstawie takich projektów powstały swoiste staromiejskie imitacje wielorodzinnej zabudowy z usługami w parterach - nie przywracające szerokości dawnych ulic, pierwotnej geometrii bloków zabudowy i podziałów własnościowych, także pozbawione plastycznej indywidualności - które uzyskały akceptacje część lokalnej społeczności i okazjonalnych turystów, w rzeczywistości wprowadzały fałszywe wyobrażenie o (rzekomo przywracanej) historycznej przeszłości. W części miast przywrócenie historycznych form zrealizowano z zastosowaniem nadmiernie uproszczonych środków formalnych. Do charakterystycznego zjawiska: poprawienia nie akceptowanego dziedzictwa blokowej zabudowy starych miast należała przebudowa wieloklatkowych budynków, polegająca na nałożeniu na prostokątne bryły parawanu - swobodnej imitacji form historycznych, z pozostawieniem powtarzalnych modułów okiennych.

Odrębne zagadnienie związane jest z układami modernistycznej urbanistyki i architektury, stanowiącymi według znacznej części opinii publicznej „dziedzictwo niechciane” (artykułowane w nadmiernym uproszczeniu); odtwarzanie historycznych struktur następuje po wyburzeniu modernistycznych budynków i powtarzalnych sekcji, projektowanych w nawiązaniu do idei Karty Ateńskiej Urbanistyki z 1933 r., których wygląd wpłynął na zatarcie historycznego charakteru zrujnowanych miast zabytkowych.

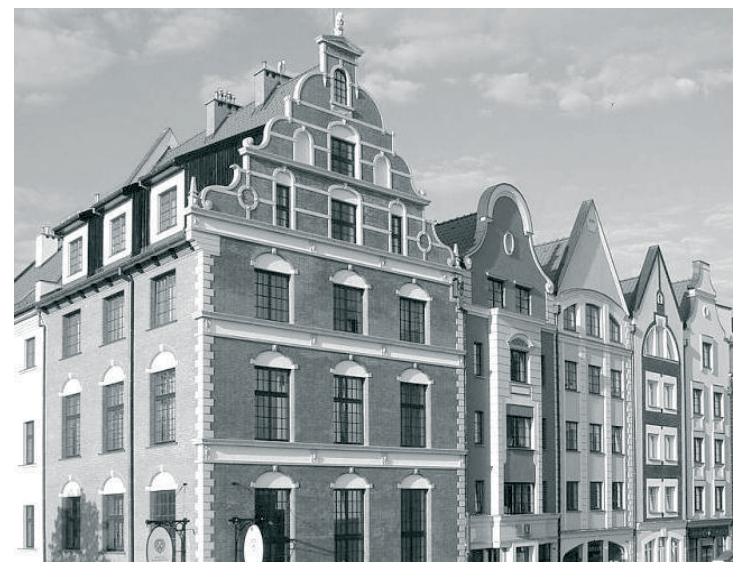

Fot. 1. Elbląg, kamienice staromiejskie 


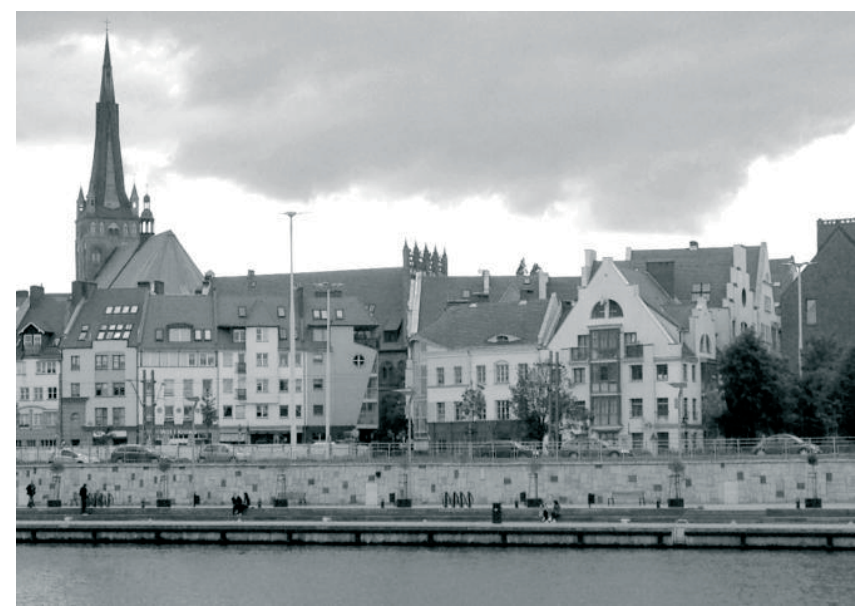

Fot. 2. Szczecin, panorama fragmentu odbudowanego Podzamcza

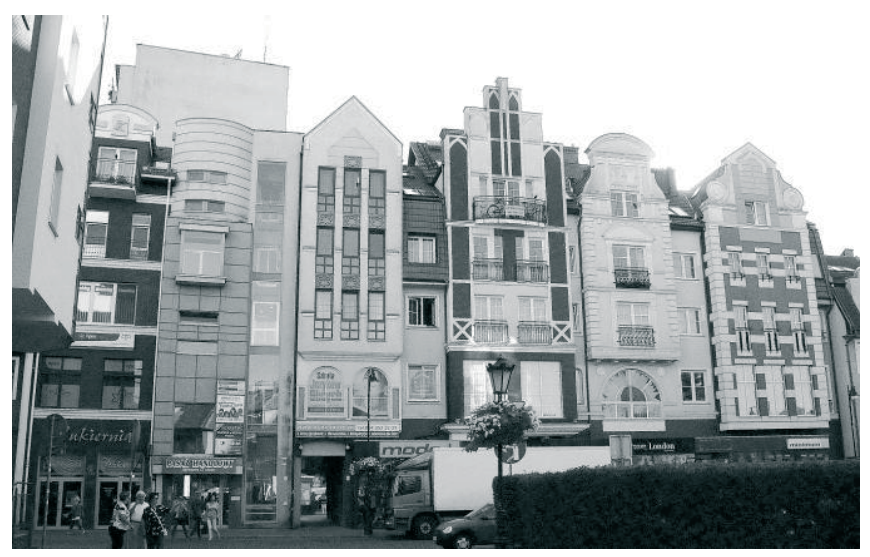

Fot. 3. Kołobrzeg, współczesne kamienice — w tle (po lewej stronie) boczna elewacja dziesięciopiętrowego bloku

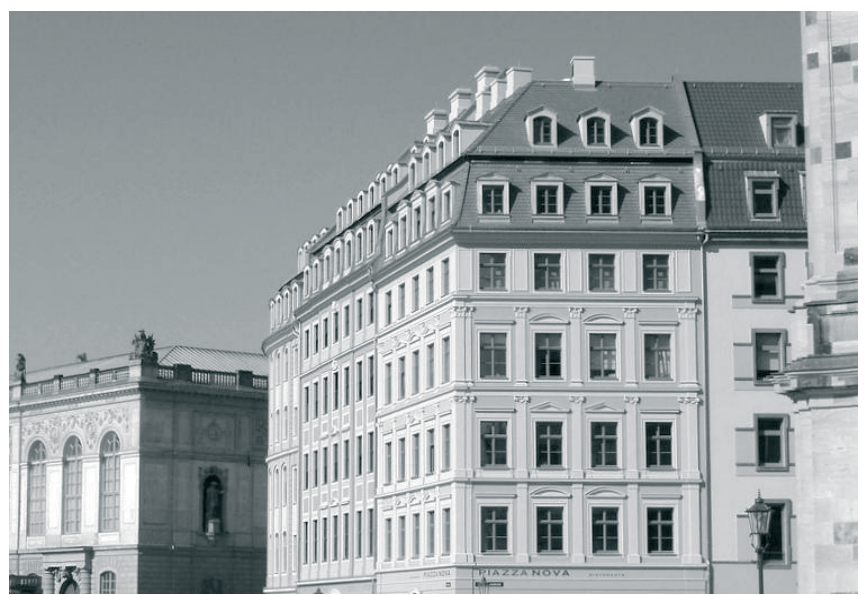

Fot. 4. Drezno, przywrócony wygląd fasad historycznego centrum 


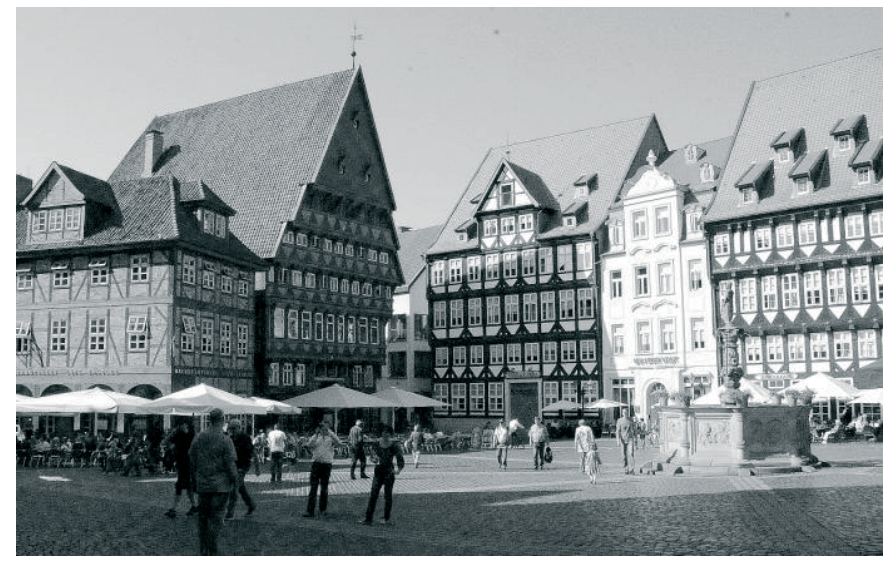

Fot. 5. Hildesheim, zrekonstruowane kamienice z przywróceniem pierzei rynku staromiejskiego

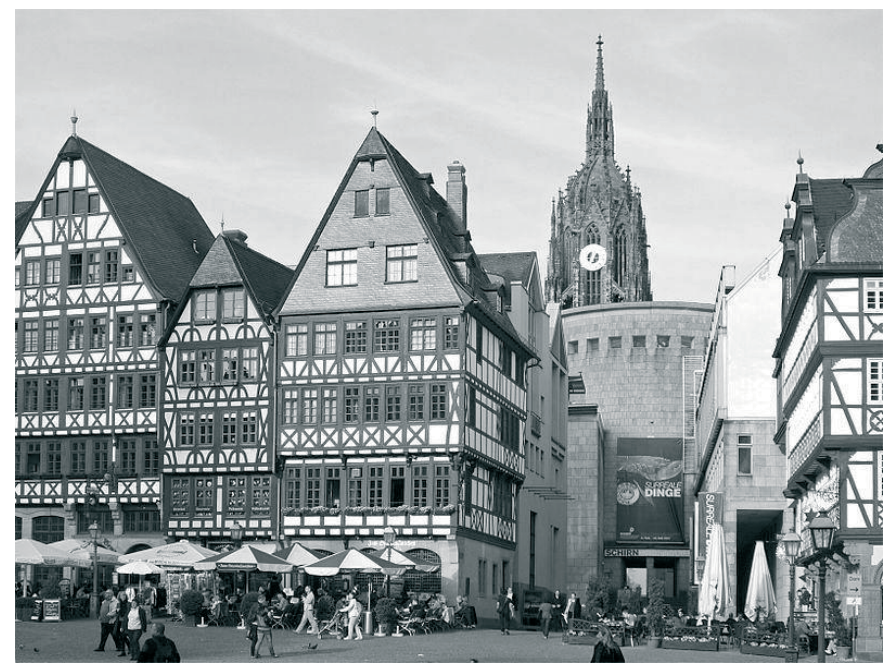

Fot. 6. Frankfurt nad Menem, zrekonstruowane kamienice przy rynku staromiejskim (Römerberg), w głębi bryła postmodernistycznego Kunsthalle i gotyckiej katedry, fot. Pedelecs, 05.05.2011, [w:] https://commons.wikimedia.org/wiki/File:Frankfurt_R\%C3\%B6merberg_090-dvfLh.jpg, online, dostęp 30.05.2016

\section{Literatura}

1. Anders W. Przywracanie ładu przestrzennego zabytkowego miasta na przyktadzie miasta w Elblagu. „Architektura”, Zeszyty Naukowe Politechniki Gdańskiej 530, Nr XXX, Gdańsk 1996.

2. $\quad$ Barthélemy J. Od Karty Weneckiej do Karty Miast Historycznych (tłum. U. Kropiwiec). [w:] Obowiązki wobec dziedzictwa a prawa rynku. Ich wpływ na zarządzanie miastami historycznych, Polski Narodowy Komitet ICOMOS, Międzynarodowe Sympozjum 14-15 września 1995, Międzynarodowe Centrum Kultury, Kraków 2012.

3. Deurer W. Gdańsk - 50 lat niedokończonej rekonstrukcji. Obraz miasta na rozdrożu. [w:] Miasto historyczne w dialogu ze współczesnością, red. J. Bogdanowski, Nadbałtyckie Centrum Kultury Gdańsk, Wydział Architektury Politechniki Gdańskiej, Gdańsk 2002. 
4. Donath M. Der Dresdner Neumarkt. Ein Platz kehrt zurück. Edition Sächsische Zeitung, Dresden 2006.

5. Düwel J., Mönninger M. (Hg.) Zwischen Traum und Trauma. Stadtplanung der Nachkriegsmoderne. DOM publishers, Berlin 2011.

6. Fiuk P. Historia miejsca - szczecińskie Podzamcze. Przywracanie tożsamości staromiejskiej dzielnicy. Trzecia Konferencja Edukacyjna, 10 XII 2010 r. pt. Szczecin i jego miejsca, red. K. Rembacka, KA druk, Szczecin. 2011-12-06.

7. Fiuk P. Neokreacja architektury szczecińskiego Podzamcza. Identyfikacja kulturowa dzielnicy staromiejskiej po 1989 roku. Materiały konferencji naukowej Społeczna rola architektury, 6-7 grudnia 2013, Podhalańska Wyższa Szkoła Zawodowa, Nowy Targ 2013.

8. Fiuk P. Architektura w miastach historycznych w Polsce od 1989 roku. Odbudowa, rekonstrukcja, retrowersja, Neokreacja i współczesna kreacja (zarys problemu). Przyszłość architektury, red. E. Przesmycka, E. Trocka-Leszczyńska, Wrocławskie Wydawnictwo Naukowe ATLA2, Wrocław 2014.

9. Helas V., Zadniček F. Das Stadtbild von Dresden. Stadtdenkmal und Denkmallandschaft. Landesamt für Denkmalpflege Sachsen, Dresden 1996.

10. Hertzig H. Frauenkirche mit Neumarkt, Dresden. Geschichte der Rekonstruktion - Konstruktion der Geschichte, [red. W. Nerdinger, M. Eisen, H. Strobl], Prestel, München-BerlinLondon-New York 2010.

11. Hildesheim - einst und heute. red. S. Abromeit, tekst H. Reyer, fot. F. Lenferink, Hildesheimer Allgemeinen Zeitung, Hildesheim 2010.

12. Kadłuczka A. Ochrona zabytków architektury. Tom I. Zarys doktryn i teorii. Prace Naukowe Instytutu Historii Architektury i Konserwacji Zabytków Politechniki Krakowskiej, Kraków 2000 .

13. Lubocka-Hoffmann M. Elblag. Stare Miasto. Elbląg 1998.

14. Lubocka-Hoffmann M. Miasta historyczne zachodniej i pótnocnej Polski. Zniszczenia i program odbudowy. Urząd Ochrony Zabytków w Elblągu, Oficyna Wydawnicza Excalibur w Bydgoszczy 2004.

15. Małachowicz E. Architektura odbudowywanych ośrodków miast historycznych. Badanie i ochrona zabytków w Polsce w XX wieku, Materiały konferencji naukowej zorganizowanej w stulecie urodzin Profesora Jana Zachwatowicza, 04.03.2000, red. A. Tomaszewski, Oficyna Wydawnicza Towarzystwa Opieki nad Zabytkami, Warszawa 2000.

16. Mak G. W Europie. Podróże przez dwudziesty wiek. Państwowy Instytut Wydawniczy, Warszawa 2004.

17. Piątek G. Wersja retro. Gdańsk, Szczecin, Elblag, Kolobrzeg - cztery starówki w poszukiwaniu sensu. Architektura Murator 1 (2011) 40-53.

18. Rodenstein M. Römer und Römerberg, Frankfurt am Main. Geschichte der Rekonstruktion Konstruktion der Geschichte, [red. W. Nerdinger, M. Eisen, H. Strobl], Prestel, MünchenBerlin-London-New York 2010.

19. Rymaszewski B. Klucze ochrony zabytków w Polsce. Ośrodek Dokumentacji Zabytków, Warszawa, 1992.

20. Siekierski M. Katedra w tle. Architektura i Biznes, Kraków, 02/2008.

21. Słomiński M., Szczecińskie Podzamcze. Staromiejska dzielnica nadodrzańska i jej odbudowa - kwartały XIV i XVII. Wyd. Spółdzielnia Mieszkaniowa „Podzamcze”, Szczecin 1998.

22. Scholz S. Budowanie $w$ historycznym otoczeniu. Zabudowa obszaru między katedra a ratuszem we Frankfurcie nad Menem i realizacja rozbudowy Albert Einstein Oberschule w modernistycznym osiedlu podkowy z lat 1926-1927 (Hufensredtung) w Berlinie-Neukölln z 1991. Architektura współczesna w mieście zabytkowym, red. A. Zwierzchowski, współpraca.: R. Eysymontt, T. Rudkowski, Konferencja naukowa 27-28.11.2000, Muzeum Architektury, Wrocław 2000.

23. Szmygin B. Ksztaltowanie koncepcji zabytku i doktryny konserwatorskiej $w$ Polsce $w X X$ wieku. Wydawnictwo Politechniki Lubelskiej, Lublin 2000. 


\title{
Transformation of old-town's districts after 1989/1990 in Poland and Germany
}

\section{Piotr Fiuk}

\author{
Faculty of Civil Engineering and Architecture, \\ West Pomeranian University of Technology Szczecin
}

\begin{abstract}
Process of transformation in old town areas is very complex issue. Effective realization of this task requires perfect synergy between single residents and local community supported by administration, public institutions, academies and private entrepreneurs. Favorable social and political circumstances and good economic situation are also key to success. Transformations in old town areas were heavily connected with political changes after 1989 in Poland and after German unification in 1990. Biggest changes took place in cities, whose historical centers have not been fully reconstructed after World War II (Elblag, Kolobrzeg, Szczecin), or were rebuild with modernist conceptions, which have not satisfied architecture specialists (art historians, conservators and architects with conservative attitude), as well as average city residents (Dresden, Hildesheim, Frankfurt am Main).
\end{abstract}

Keywords: Transformation, rebuilding, reconstruction, architecture of old cities, modern tenement house. 